\title{
The Canal da Piracema at Itaipu Dam as a fish pass system
}

\author{
Sérgio Makrakis*,**, Luiz Carlos Gomes***, Maristela Cavicchioli Makrakis**, \\ Domingo Rodriguez Fernandez**** and Carla Simone Pavanelli*****
}

The Canal da Piracema is the longest (nearly $10 \mathrm{~km}$ ) fish pass system in the world. The construction of this fish pass was somehow controversial, because it connected two distinct ichthyofaunistic provinces. This study evaluated the ichthyofauna present in the Canal da Piracema and the abundance and distribution of long-distance migratory fish species along this fish pass system (evaluated possible selectivity). The Canal da Piracema was shown to be difficult to sample because of its environmental heterogeneity: artificial ponds, ladders and nature-like fish pass. To solve this problem, we used several fishing gears, adequate for the several biotopes present (unstructured and structured littoral were sampled with seining nets and electrofishing; lentic were sampled with gillnets and longlines (deeper areas); and rapid water areas were sampled with cast nets). The ichthyofauna of the Canal da Piracema followed the pattern for South America and the Paraná River, with a predominance of Characiformes and Siluriformes. The most representative families were Characidae, Anostomidae, Pimelodidae and Loricariidae. We captured 116 species (17 were long-distance migratory) during the period studied. Small-sized species were predominant in unstructured and structured littoral areas, especially Bryconamericus exodon and Apareiodon affinis. The most abundant species was Hypostomus spp. in lentic areas, followed by Iheringichthys labrosus. Hoplias aff. malabaricus predominated in deeper lentic areas. Long-distance migratory species were abundant in rapid waters; they were Prochilodus lineatus and Leporinus elongatus. The sharp reduction in the number of species, including migratory ones, is an indication that the Canal da Piracema is selecting the species that ascend it. Therefore, the search for information on the efficiency of the various fish passes present in the Canal da Piracema is fundamental, to facilitate upward movements of fish. If this is reached, this polemic fish pass has the potential to contribute to the conservation of fish stocks in Itaipu Reservoir and upstream stretches, because of the presence of spawning and development (nurseries) areas for migratory species.

O Canal da Piracema é considerado o maior sistema de transposição para peixes no mundo, com $10 \mathrm{~km}$ de extensão. A sua construção foi controversa, pois viabilizou a conexão entre duas províncias ictiofaunísticas distintas. Este trabalho buscou avaliar a ictiofauna presente no Canal da Piracema, a abundância e distribuição das espécies migradoras de longa distância ao longo deste sistema de transposição (indicação de seletividade). O Canal da Piracema mostrou-se difícil de ser amostrado, devido a sua elevada heterogeneidade ambiental: lagos artificiais, escadas e canais semi-naturais, sendo utilizados diversos aparelhos de pesca, adequados aos diversos biótopos (litoral não estruturado e estruturado, amostrados com redes de arrasto e pesca elétrica; lêntico, amostrado com redes de espera e espinhel (mais profundo); e águas rápidas, amostradas com tarrafas). A ictiofauna presente seguiu o padrão para a América do Sul e rio Paraná, com amplo domínio de Characiformes e Siluriformes, sendo Characidae, Anostomidae, Pimelodidade e Loricariidae as famílias mais representativas. Ao todo foram capturadas 116 espécies sendo que 17 eram migradoras de longas distâncias. Nas regiões litorâneas estruturadas e não estruturadas do Canal da Piracema, as capturas se restringiram às espécies de pequeno porte, sendo as mais representativas Bryconamericus exodon e Apareiodon affinis. Nas áreas lênticas houve predomínio de Hypostomus spp., seguidos de Iheringichthys labrosus. Nas áreas lênticas profundas a espécie mais capturada foi Hoplias aff. malabaricus. Nas áreas de águas rápidas houve maior captura de espécies migradoras de longa distância, sendo Prochilodus lineatus e Leporinus elongatus as mais capturadas. A redução acentuada, no sentido de jusante a montante, inclusive das migradoras, indica que o Canal da Piracema está sendo seletivo. Então, a busca de informações dos vários tipos de sistemas de transposição existentes ao longo do Canal da Piracema

\footnotetext{
*Curso de Pós-Graduação em Ecologia de Ambientes Aquáticos Continentais, Universidade Estadual de Maringá, Avenida Colombo, 5790. 87020-9000 Maringá, PR, Brazil.

**Universidade Estadual do Oeste do Paraná, Centro de Engenharias e Ciências Exatas, Getech. Rua da Faculdade, 645. $85903-330$ Toledo, PR, Brazil.makrakis@terra.com.br(SM); mcaviccm@hotmail.com (MCM)

***Universidade Estadual de Maringá, Departamento de Biologia, Nupelia, CNPq Researcher. Av. Colombo, 5790. 87020-9000 Maringá, PR, Brazil.lcgomes@nupelia.uem.br

****Itaipu Binacional, Setor de Ictiologia. Av. Tancredo Neves, 6731.85866-900 Foz do Iguaçu, PR, Brazil. domingo@itaipu.gov.br *****Universidade Estadual de Maringá, Nupelia. CNPq Researcher. Av. Colombo, 5790. Maringá, PR, Brazil. 87020-900. carlasp@nupelia.uem.br
} 
é fundamental para permitir a movimentação ascendente de peixes. Se isto for alcançado, este polêmico mecanismo de transposição tem potencial para contribuir para a conservação dos estoques de peixes no reservatório de Itaipu e segmento a montante, devido a presença de áreas de desova e crescimento necessários para as espécies migradoras.

Key words: Migratory fish, Fish passage, Fishway, Paraná River.

\section{Introduction}

Fish pass systems are structures that fish generally ascend by swimming or leaping, helping them to move freely when barriers are added to the natural environment, as in the case of reservoir dams. Over time, different kinds of fish pass systems have been developed, mainly ladders, elevators, locks, and bypass channels (Orsborn, 1987; Clay, 1995; Miranda, 2001; Larinier, 2002a). These fish passes have a long history, beginning in Europe three hundred years ago (Clay, 1995). There are approximately 13,000 fish passes in the world, and most of them are in Europe and North America (Martins, 2000). These systems were developed for the ichthyofauna of temperate regions, but are also widely used in tropical regions (Agostinho et al., 2002). The construction of fish pass systems in the South America began in the last century, and in Brazil the first fish ladder was constructed in the Pardo River in 1911.

The large migratory fishes of the Neotropical region can ascend ladders and other fish passes, and their efficiencies depend on their design and position in relation to the dam (Quirós, 1988). Ladders are the main fish pass system constructed in Brazil. However, their construction has not generally taken into consideration the technical characteristics of the dam (type, slope, discharge and position in relation to the dam) and the nature of the ichthyofauna, and they are generally selective (Agostinho et al., 2002, 2007). Among the other systems, fish elevators are present (at Engenheiro Sergio Motta Dam on the Paraná River; and at Funil on the Grande River), in addition to many locks. Nevertheless, the majority of the fish passes were never monitored in Brazil (Agostinho et al., 2007).

The Canal da Piracema is a fish pass system constructed at Itaipu Dam (completed in December, 2002), linking the Paraná River to Itaipu Reservoir. It was the first lateral fish pass constructed in a large reservoir in South America. It is the longest in the world (Carosfeld, 2004), and this system could allow long-distance migratory species to find suitable spawning and nursery areas in tributaries of Itaipu Reservoir and in the floodplain located upstream (Agostinho et al., 1993; Gomes \& Agostinho, 1997). Its construction was somehow controversial, because it made possible a connection between two distinct ichthyofaunistic provinces. These provinces were formerly separated by a natural barrier, the Sete Quedas waterfalls (Bonetto, 1986), which were inundated when Itaipu Reservoir was completed; Itaipu Dam became the lower limit between the provinces (Agostinho \& Júlio Jr., 1999). This connection can potentially introduce species into the upper parts which may lead to ecological impacts (especially hybridizations and disappearance or extinction of some fish species). Thus, we conducted this study to evaluate the ich- thyofauna in the Canal da Piracema. Specifically, the study was intended to i) characterize the ichthyofauna that uses this fish pass system and ii) evaluate the abundance and distribution of the species, especially long-distance migratory ones, along the Canal da Piracema, the main reason for its construction.

\section{Material and Methods}

\section{Study area}

The Canal da Piracema begins at Itaipu Reservoir and extends downstream to the Paraná River below the dam (Fig. 1). The upstream entrance is located on the left bank, $6.6 \mathrm{~km}$ east of the spillway and $4.8 \mathrm{~km}$ from the closest turbine. At the Canal da Piracema entrance, mean depth of the reservoir is 3.5 $\mathrm{m}$. The downstream entrance is located on the left bank of the Paraná River, $2.5 \mathrm{~km}$ below the dam. The mean discharge of the Canal da Piracema is $12 \mathrm{~m}^{3} / \mathrm{s}$. It is $10 \mathrm{~km}$ long and includes $6.7 \mathrm{~km}$ of the Bela Vista River bed, as well as several fish ladders and artificial ponds (resting pools) (for a more detailed description, see Fiorini et al., 2006).

The first section of the Canal da Piracema from downstream to upstream is a nature-like fish pass, the Bela Vista River (RIBE), which flows into the Paraná River. This stream was widened to $4-6 \mathrm{~m}$ and deepened to $0.5-2.0 \mathrm{~m}$. The total length of this stretch is approximately $6.7 \mathrm{~km}$, with a $4.0 \%$ mean slope. Rocks were removed to eliminate the higher waterfalls in parts of this river. The Bela Vista River enters the Paraná River at an approximately $60^{\circ}$ angle from the downstream direction, which apparently may decrease the attractiveness of the Canal da Piracema. In this area, the Paraná River is about $720 \mathrm{~m}$ wide, which varies depending on discharge. The mean discharge of the Paraná River is approximately $10,000 \mathrm{~m}^{3} / \mathrm{s}$, and the water velocity is $2.0 \mathrm{~m} / \mathrm{s}$ at the surface. The Brasília Creek runs for $800 \mathrm{~m}$ to the Bela Vista River. This stream was widened to $5 \mathrm{~m}$ and deepened to 0.5 $1.0 \mathrm{~m}$. Its banks have a 4:1 slope (vertical: horizontal). The slope of Brasília Creek is $4.0 \%$, and this section is the shallowest and the most turbulent.

The next section is a ladder, herein named CABV, constructed of reinforced concrete, $5 \mathrm{~m}$ wide with a $6.25 \%$ slope, which extends for about $150.5 \mathrm{~m}$. It is rectangular in crosssection, $5.0 \mathrm{~m}$ wide and $2.5 \mathrm{~m}$ high, and it is provided with concrete barriers spaced every $4 \mathrm{~m}$ to reduce the water velocity. The concrete barriers have a $1 \mathrm{~m}$ opening, alternately on the right and left side of each barrier.

The central elements of the Canal da Piracema are two artificial ponds, a small lake (herein named LAIN, area of 1.2 ha and depth of $4 \mathrm{~m}$ ) and a large lake (herein name LAPR; area of 14 ha and depth of $5 \mathrm{~m}$ ), which are resting pools for fish. 
The banks are covered with soil, vegetation, and rocks of different sizes. The LAIN is drained by the fish ladder into the Brasília Creek, through a short section fitted with concrete deflectors. These two ponds are connected by a fish ladder (herein named CAIN), constructed of reinforced concrete and equipped with transverse barriers to control the water velocity. The ladder winds between the resting pools, and is $521 \mathrm{~m}$ long with a $1.5 \%$ slope.

The next section is a fish ladder (herein named CAAT) stretching $1.6 \mathrm{~km}$. This ladder has a trapezoidal cross-section, constructed in landfill, with a maximum width of $12 \mathrm{~m}$ and banks with a slope of 2:3. The bottom and sides of this ladder are covered with riprap, as in the first part. This section has a mean slope of $3.1 \%$ in the first stretch, $2.0 \%$ in the middle, and $0.8 \%$ in the final stretch. This ladder in turn opens into the LAPR. Another artificial pond (herein named LAGR) with 0.5 ha in area and a mean depth of $3.0 \mathrm{~m}$ is located after this ladder. Sides and bottom are covered with irregularly shaped riprap; it was also constructed as a fish resting pool. A fish ladder, herein named CATR, is above this pond which extends for $2.4 \mathrm{~km}$, with the first $0.73 \mathrm{~km}$ of the ladder excavated in a trench. This ladder is trapezoidal in cross-section, $8 \mathrm{~m}$ wide at the bottom, with a 2:3 slope of the embankment, excavated in alluvial basalt. Its bottom and sides are covered up to the water level with irregularly shaped riprap, as well as concrete deflectors, spaced to reduce the flow velocity. These deflectors are $0.6 \mathrm{~m}$ high, with lateral openings of $1.0 \mathrm{~m}$, located on alternate sides in relation to the banks. The slope is $5.0 \%$ on average in the beginning stretch, $0.7 \%$ in the middle, and $5.0 \%$ in the final stretch.

The last section is the area of water intake, herein named DIRE. This area is formed by concrete water-intake structures and the stabilization pond. The water intake and the stabilization pond have a mean depth of $3.3 \mathrm{~m}$ and an area of 0.4 ha. The DIRE is composed of three floodgates, $2.0 \mathrm{~m}$ in height, that maintain the maximum level of the stabilization

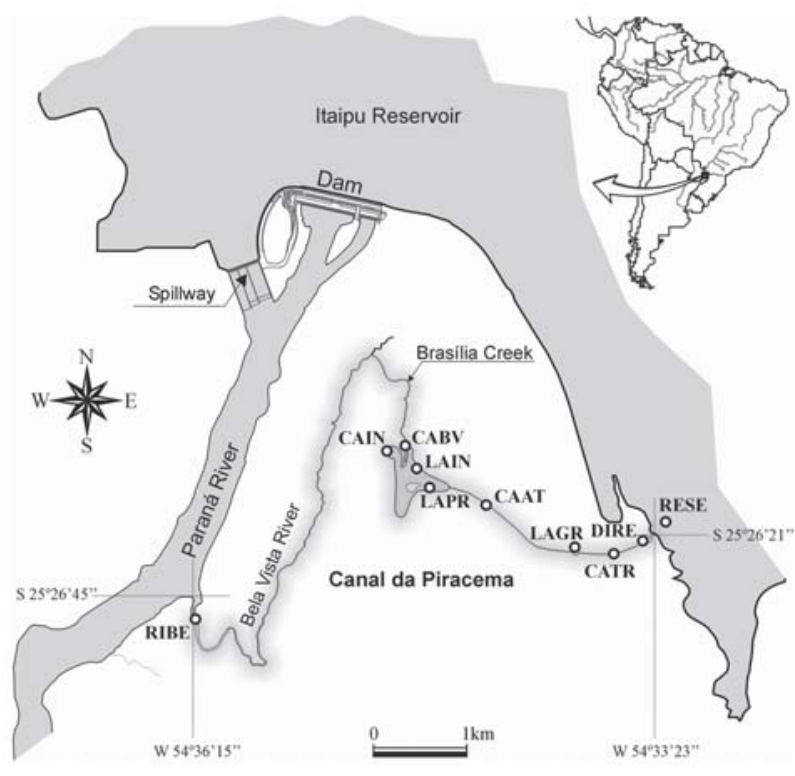

Fig. 1. Canal da Piracema and sampling stations, including the Paraná River.

pond $0.45 \mathrm{~m}$ below the surface level of Itaipu Reservoir, to limit the velocities in the intake sluices to less than $3.0 \mathrm{~m} / \mathrm{s}$ along the Canal.

\section{Data collection}

The Canal da Piracema was evaluated from April, 2004 through May, 2005. Samplings were conducted monthly, except in June and July, and because the heterogeneity of biotopes in this fish pass system (resting pools, ladders, and nature-like fish pass), it was expected that different species would inhabit these locations. Therefore, to identify the species that use the Canal da Piracema, several fishing gears were employed in 11 stations (Table 1).

Table 1. Location of the sampling stations along the Canal da Piracema, distance from the Paraná River (km), and the fishing gear used (GI: gillnets and trammel nets; LL: longlines; SN: seining nets; CN: cast nets, FP: fishing pole; and EL: electrofishing). Numbers in parentheses are the times of day at which the different gear was used.

\begin{tabular}{lcl}
\hline Location & $\begin{array}{c}\text { Distance from } \\
\text { the Paraná River (km) }\end{array}$ & Fish sampling methods and time periods \\
\hline Bela Vista River Mouth & 0.5 & $\begin{array}{l}\text { GI and LL (16:00-8:00); SN (7:00 e 19:00); } \\
\text { CN (10:00-12:00, 14:00-16:00); EL (17:00-18:00) }\end{array}$ \\
Along the Bela Vista River and Brasília Creek (RIBE) & $0.6-6.6$ & CN (10:00-12:00, 14:00-16:00) \\
Bela Vista River Mouth Drainage Canal (CABV) & 6.7 & CN (10:00-12:00, 14:00-16:00) \\
LAIN (fish resting pool) & 7.0 & GI (16:00-8:00), SN (7:00 e 19:00); \\
CAIN (fish ladder) & 7.4 & FP (10:00-11:00, 14:00-15:00) \\
LAPR (fish resting pool) & 7.7 & CN (10:00-12:00, 14:00-16:00) \\
CAAT (fish ladder) & 8.6 & CN (16:00-8:00); SN (7:00 e 19:00); FP (10:00-11:00, \\
LAGR (fish resting pool) & 9.4 & GI (16:00-8: 14:00-16:00); FP (10:00-11:00, 14:00-15:00) \\
CATR (fish ladder) & 9.7 & CN (10:00-12:00, 14:00-16:00) \\
DIRE (water intake) & 10.1 & FP (10:00-11:00, 14:00-15:00); EL (17:00-18:00) \\
Itaipu Reservoir & 10.3 & GI and LL (16:00-8:00); SN (7:00 e 19:00) \\
\hline
\end{tabular}


The gillnets (mesh sizes 2.4, 3, 4, 5, 6, 7, 8, 10, 12, 14, 16, and trammel nets with meshes of 6,7 , and $8 \mathrm{~cm}$ between opposite knots) were set out in late afternoon $(16: 00 \mathrm{~h})$, and inspected every $4 \mathrm{~h}$, until 8:00 $\mathrm{h}$ in the morning of the following day (effort of $16 \mathrm{~h}$ ). Longlines were $150 \mathrm{~m}$ long, with 30 hooks baited with live bait (Gymnotus spp.) and operated as with the gillnets. Cast nets (mesh sizes 6, 7, 8, 10, 12, and 14 $\mathrm{cm}$ between opposite knots) were operated in a standardized manner (5 throws each), in the morning (10:00 to 12:00 h) and afternoon (14:00 to 16:00 h). Fishing rods (with artificial bait) were also operated for one hour, in the morning (10:00 to 11:00 $\mathrm{h}$ ) and afternoon (14:00 to 15:00 h). Seining nets were also operated at dawn (7:00 h) and at dusk (19:00 h). Finally, electrofishing ( $2500 \mathrm{~W}$ generator, $1000 \mathrm{~V}$ output, $60 \mathrm{~Hz}$ DC) was operated in the afternoon, for 15 minutes (between 17:00 and 18:00 h).

\section{Data analysis}

Voucher specimens are housed in the Nupélia fish collection. The collected fish were identified to the species level according to Britski et al. (1999) and Graça \& Pavanelli (2007). Their total and standard lengths were measured (except for those caught by electrofishing, which were only recorded as present in the samples). For analysis, the 11 stations sampled were grouped considering a fish ladder and a resting pool, except for the nature-like fish pass (RIBE), into five segments: I: RIBE; II: CABV and LAIN; III: CAIN and LAPR; IV: CAAT and LAGR; V: CATR and DIRE; and, last, Itaipu Reservoir.

In order to explore the diverse biotopes of the Canal da Piracema, which limit the use of the different gear types in a standardized manner at each station, the samples obtained with each type of gear were described. The biotopes sampled were: i) unstructured littoral (sampled with seining nets); ii) structured littoral (by electrofishing); iii) lentic waters (with gillnets and longlines, the latter in deeper areas); and iv) rapid waters (with cast nets). The catch data per sample (controlled for type of gear) were expressed in a presence/absence matrix. Patterns of fish composition in the samples were evaluated using a correspondence analysis (CA; Gauch, 1982), which is less influenced by zeros (Olden et al., 2001). The axes with eigenvalues higher than 0.20 were retained for interpretation, as recommended by Matthews (1998). The scores of the CA were tested by one-way analysis of variance (ANOVA) considering biotopes as the factor and a Tukey's test was applied when significant differences were detected between averages (level of significance of $\mathrm{P}<0.05$ ). The ANOVA assumptions were tested by Shapiro-Wilk (normality) and Levene (homoschedasticity) tests.

The number of individuals caught per biotope, for the principal species and for all species grouped by reproductive strategy, was analyzed graphically. The reproductive strategies considered were: long-distance migratory species (LDMI), sedentary with no parental care (SNPC), sedentary with parental care (SPC), sedentary with internal fertilization and external development (SIFE), sedentary with internal fertilization and internal development (SIFI), and unknown
(UNK) (Vazzoler, 1996; Agostinho et al., 2003; Suzuki et al., 2004).

To evaluate the distribution of species along the Canal da Piracema, the data were analyzed separately for each segment, considering the total number of species caught in each of them, as well as the number of exclusive species. The number of species caught in segments I, III, and Reservoir, where gillnets, seining nets and longlines were operated in a standardized way, was compared to remove the effect of the different types of fishing gear used. Finally, because the principal objective of the study was to determine the movements of migratory species, their occurrence along this fish pass system was analyzed in more detail. Thus, a reduction in the number of species ascending the Canal da Piracema would be an indication of selectivity, i.e., some species are not succeeding in passing through parts of the system.

\section{Results}

\section{The ichthyofauna of the Canal da Piracema}

The ichthyofauna along the Canal da Piracema was composed of 116 species, from 25 families, 9 orders and 2 classes. The species list and their taxonomic position, based on Reis et al. (2003), are presented in Appendix 1. The predominant orders were Characiformes (57 species) and Siluriformes (30 species). Characidae and Anostomidae were the most important families, with 30 and 14 species, respectively (Fig. 2). Of

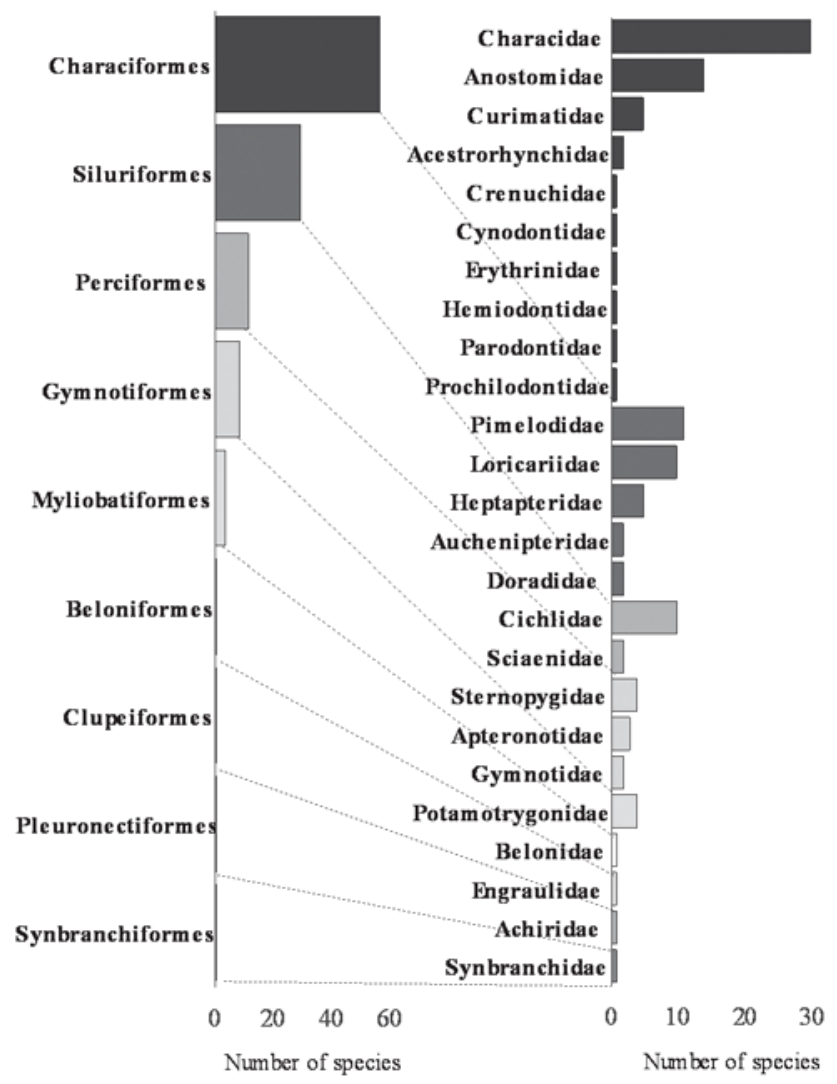

Fig. 2. Species number by order and family. Dotted lines delimit the families in relation to the orders. 
the total number of species, 17 were long-distance migratory (LDMI), 68 were sedentary with no parental care (SNPC), 22 were sedentary with parental care (SPC), 2 were sedentary with internal fertilization and external development (SIFE), 4 were sedentary with internal fertilization and internal development (SIFI), and 3 were considered unknown (UNK).

During the collection period, 21,987 individuals were caught. The most frequent species in the catch was $B$. exodon with 8,116 individuals, followed by $A$. affinis with 6,447 individuals. The largest part (80.1\%) of the captured individuals belonged to the SNPC reproductive strategy (sedentary without parental care), followed by SPC (sedentary with parental care) with $15.2 \%$. Migratory species contributed $3.8 \%$ of the number of caught individuals, and the most abundant species were $P$. lineatus and L. elongatus.

The different types of gear used made it possible to sample the highly diverse ichthyofauna inhabiting the biotopes along the Canal da Piracema. The array of biotopes apparently makes it possible for many species to move along this fish pass, as well as for other species to reproduce and develop.
The correspondence analysis (CA), applied to determine whether the different biotopes support different ichthyofaunas, yielded the first two axes with eigenvalues greater than 0.20 , which were therefore retained for interpretation. The resulting ordination (Fig. 3a) was difficult to interpret. On Axis 1, the concentration of samples obtained in rapid waters (cast nets in Fig. 3a) was evident, but located to the right, showing that they were more similar. On the same axis, the remaining samples were dispersed, demonstrating the importance of using several types of gears to complete surveys. For Axis 2, it was more evident that samples obtained in lentic areas (gillnets in Fig. 3a) positioned higher in the ordination.

These patterns became more evident when the axes were analyzed separately, controlling for biotope. Thus, for Axis 1, ANOVA showed significance $(\mathrm{F}=8.46 ; \mathrm{P}<0.001)$ and Tukey's test showed that the rapid waters (sampled with cast nets) contained a more differentiated ichthyofauna (Tukey; P < 0.05 ; Fig. 3b). For Axis 2, ANOVA also showed significance $(\mathrm{F}=5.62 ; \mathrm{P}=0.001)$, with the ichthyofaunas of the lentic
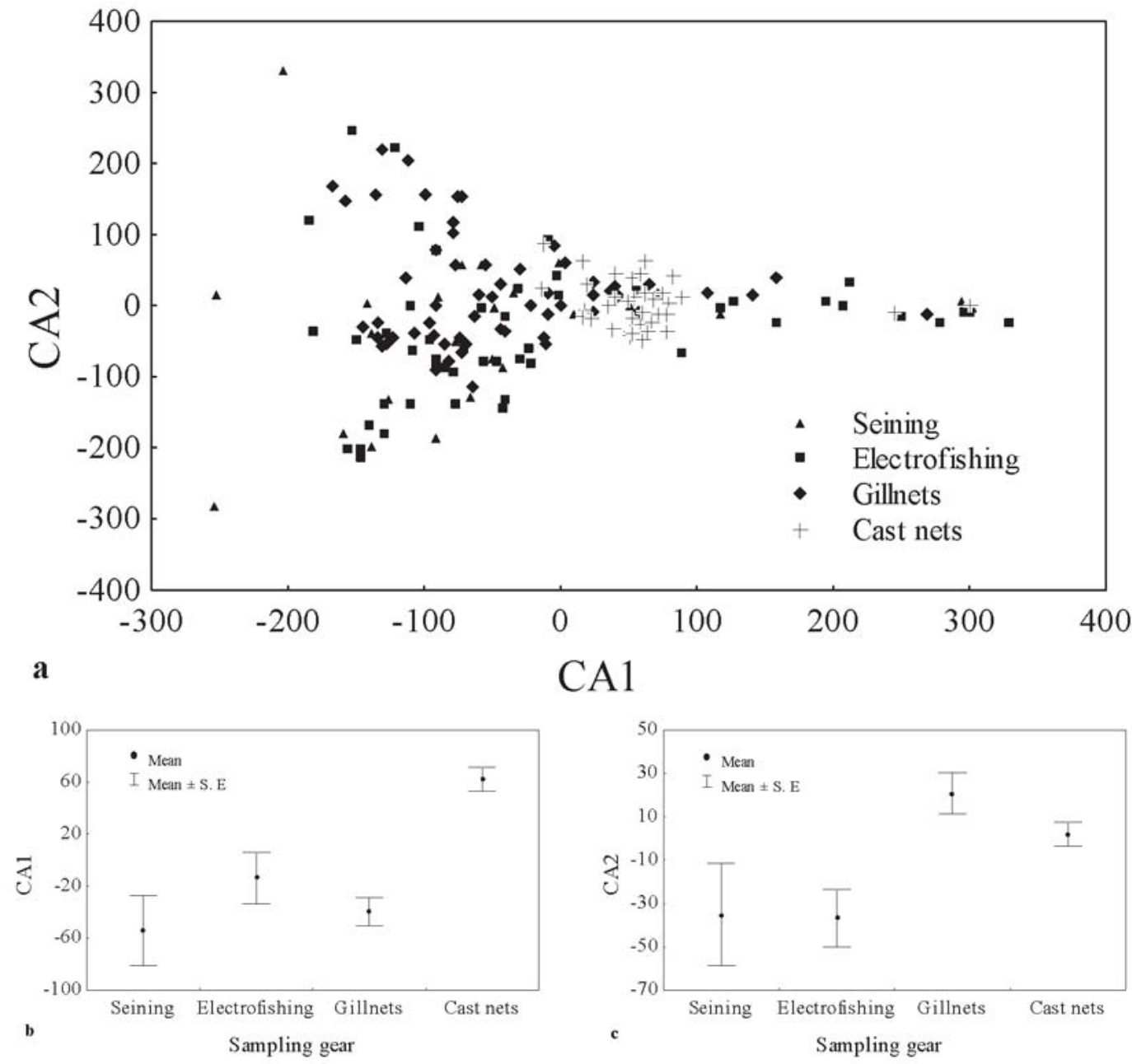

Fig. 3. Ordination (correspondence analysis - CA; Axis 1-CA1; Axis 2-CA2) of the samples taken with seining nets, electrofishing, gillnets, and cast nets, at different stations located in the Canal da Piracema (a). Representation of the mean scores by fishing gears in axis 1 (b) and axis 2 (c). 
waters (sampled with gillnets) and rapid waters (sampled with cast nets) being similar, and both of them differing again from the fauna in the littoral area (unstructured and structured, sampled with seining nets and electrofishing, respectively) (Tukey's test; $\mathrm{P}<0.05$; Fig. 3c). The assumptions of normality (Shapiro-Wilk; $\mathrm{P}>0.05$ ) and homoscedasticity (Levene; $\mathrm{P}$ $>0.05)$ were met.

Therefore, on Axis 1, the ichthyofauna that inhabited rapid waters was differentiated from the others by the large number of migratory species, especially L. elongatus and P. lineatus. On Axis 2, the littoral biotopes showed greater similarity, as a result of the occurrence of small-sized species such as $B$. exodon and S. pappaterra.
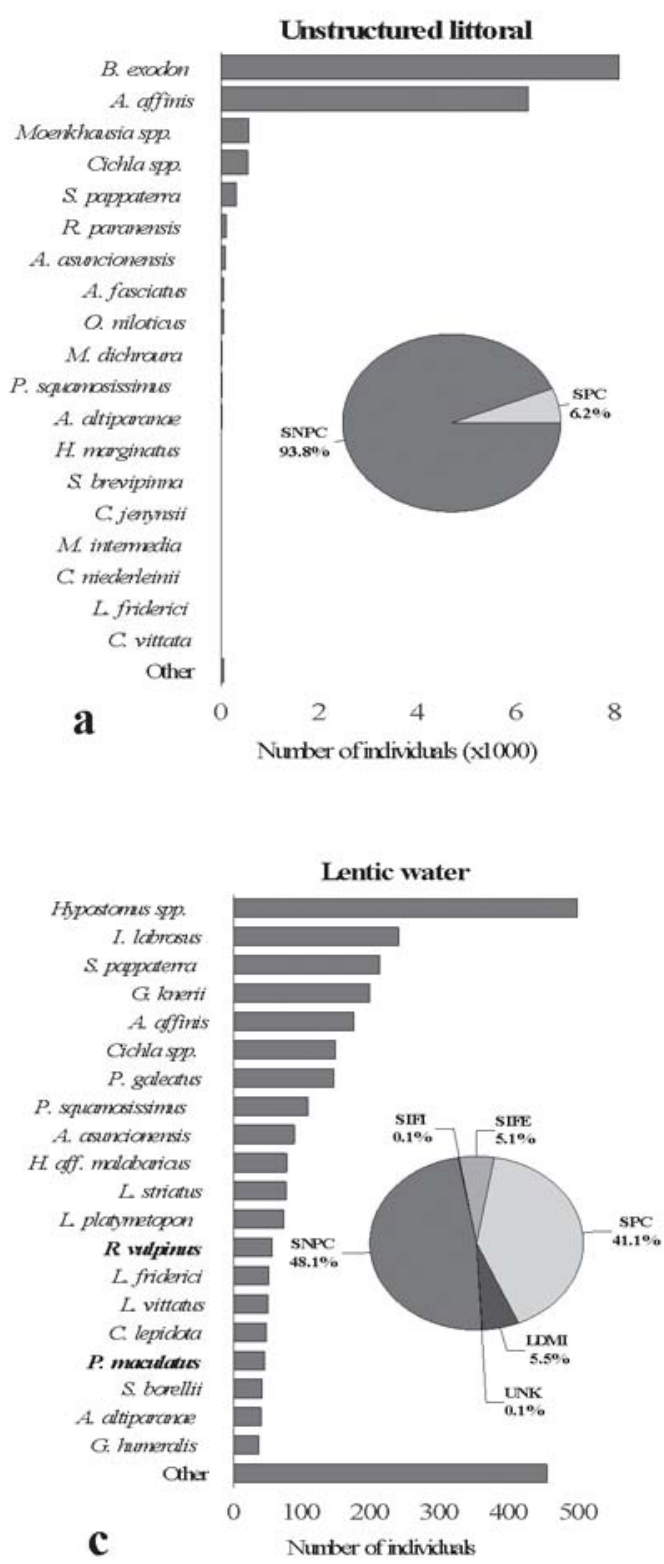

The differences in the number of individuals caught were more apparent, but because of the different selectivity of the various fishing gears, the data are not comparable. The catches were limited to small-sized species in the structured littoral areas, with a total of 16,689 individuals, the most important being B. exodon and A. affinis, with 8,115 and 6,264 individuals, respectively. The great majority (90.8\%) belonged to the reproductive category SNPC (Fig. 4a). Long-distance migratory species were not caught in these biotopes.

A total of 2,870 individuals were caught in lentic areas. Hypostomus spp. (497 individuals), followed by I. labrosus (239 individuals) predominated in this biotope. The reproductive strategies for the majority of individuals caught were
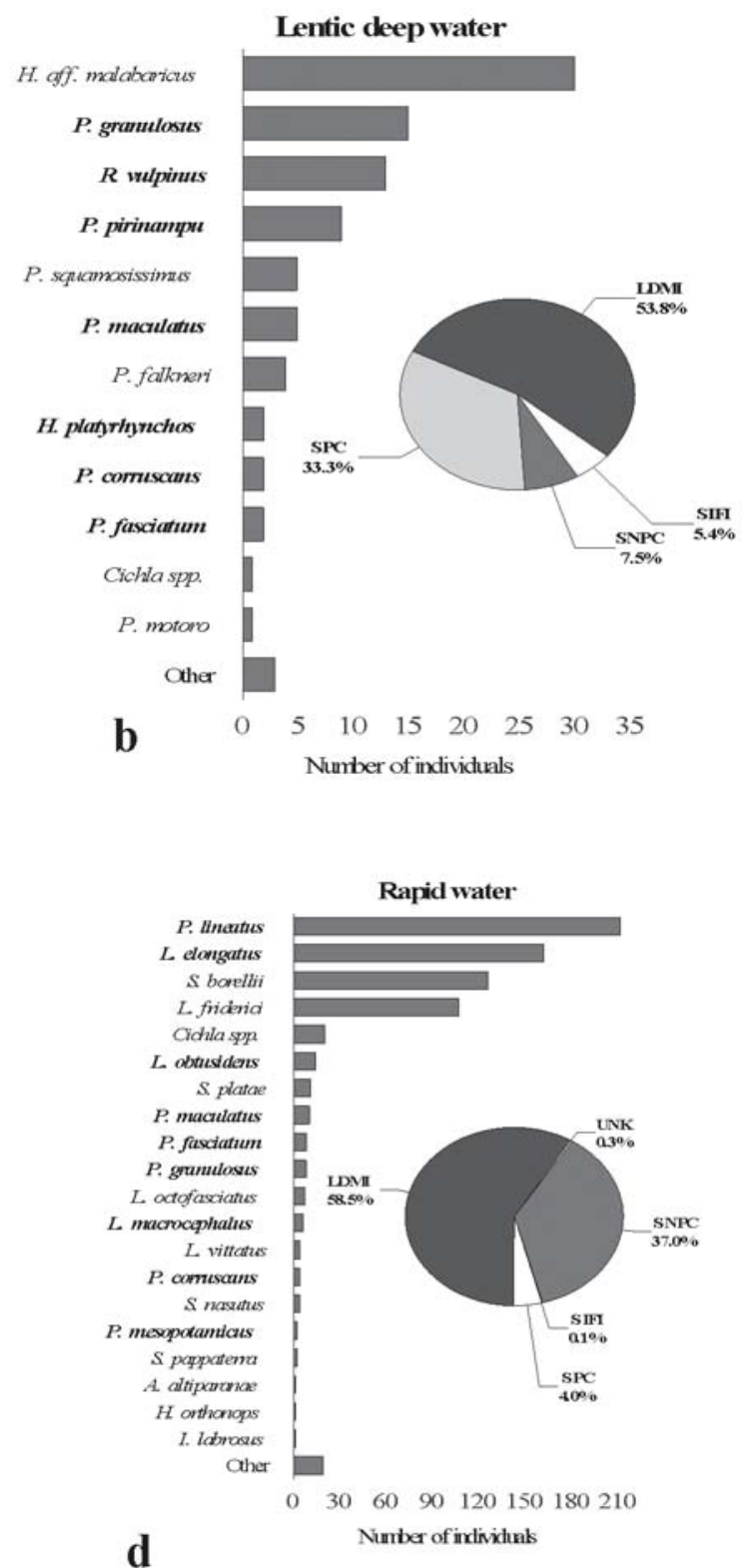

Fig. 4. Number of individuals of the principal species, according to reproductive strategy by different biotope: LDMI (long-distance migratory species), SNPC (sedentary with no parental care), SPC (sedentary with parental care), SIFE (sedentary with internal fertilization and external development), SIFI (sedentary with internal fertilization and internal development) and UNK (unknown). 
Table 2. Distribution of the long distance migratory species along the Canal da Piracema, by segment and distance (km) from the Paraná River.

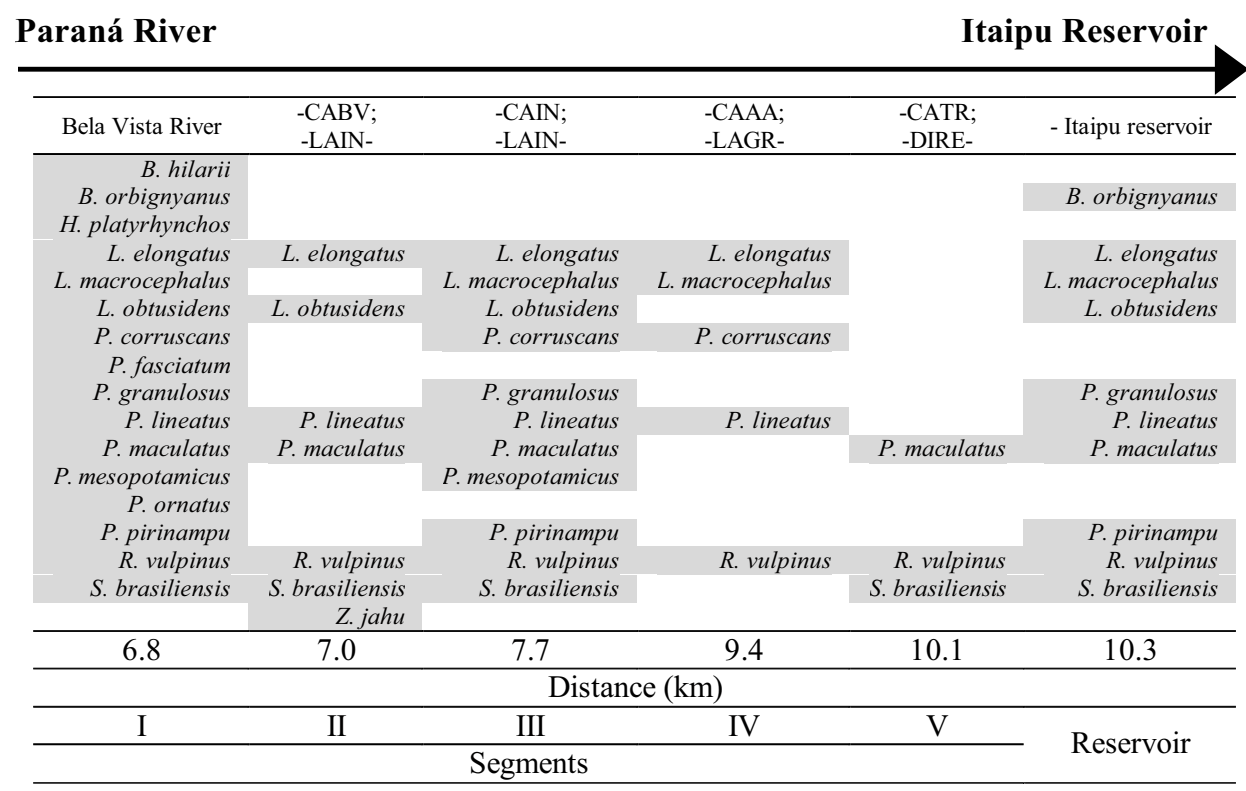

SNPC (48.1\%), followed by SPC with 41.1\% (Fig. 4b). Longdistance migratory species (LDMI) contributed only $5.5 \%$ of the total.

The species most often caught was $H$. aff. malabaricus in deep lentic areas, sampled with the use of longlines, with 30 individuals. However, in regard to reproductive strategy, longdistance migratory were prominent (LDMI), comprising 53.8\% of the total, followed by SPC with $33.3 \%$. The total of individuals caught in this biotope was 108 (Fig. 4c).

We especially caught long-distance migratory species (LDMI) in rapid water areas (745 individuals), which represented $58.5 \%$ of the total, followed by SNPC species with $37.0 \%$. The main long-distance migratory species caught were P. lineatus and L. elongatus, with 211 and 162 individuals, respectively (Fig. 4d).

The possibility that the Canal da Piracema might have a selective effect on the fish species was evaluated by their presence along this fish pass system. The total number of species caught in each segment was highly variable. More species were caught in Segments I, III, and Reservoir, with 89, 69 and 49 species, respectively. The segments with fewer species were, in decreasing order, II, IV, and V, with 47, 41, and 33 species, respectively. The higher number of species in Segment I indicates that many species did not succeed in reaching the upper parts of the Canal da Piracema.

This was easily perceived when we analyzed the number of species exclusive to each segment. The highest number was recorded for Segment I (24 species), followed by Segment II (6). Segments II, IV, and V had 2, 3 and 2 exclusive species, respectively. In Itaipu Reservoir near the entrance to the Canal da Piracema, no exclusive species were recorded.

To remove the effect of the gear used, species richness was evaluated for Segments I (beginning of the fish pass system) and III (middle) and Reservoir (end of the fish pass system), where the same gear types were used, and in a standardized way (Fig. 5). The same decrease in species upward the Canal da Piracema was observed, with a reduction from 51 (Segment I) to 42 (Reservoir) species, caught with gillnets; and from 13 (Segment I) to 4 (Reservoir), caught with longlines. The number of species caught with seining nets was similar in all three segments.

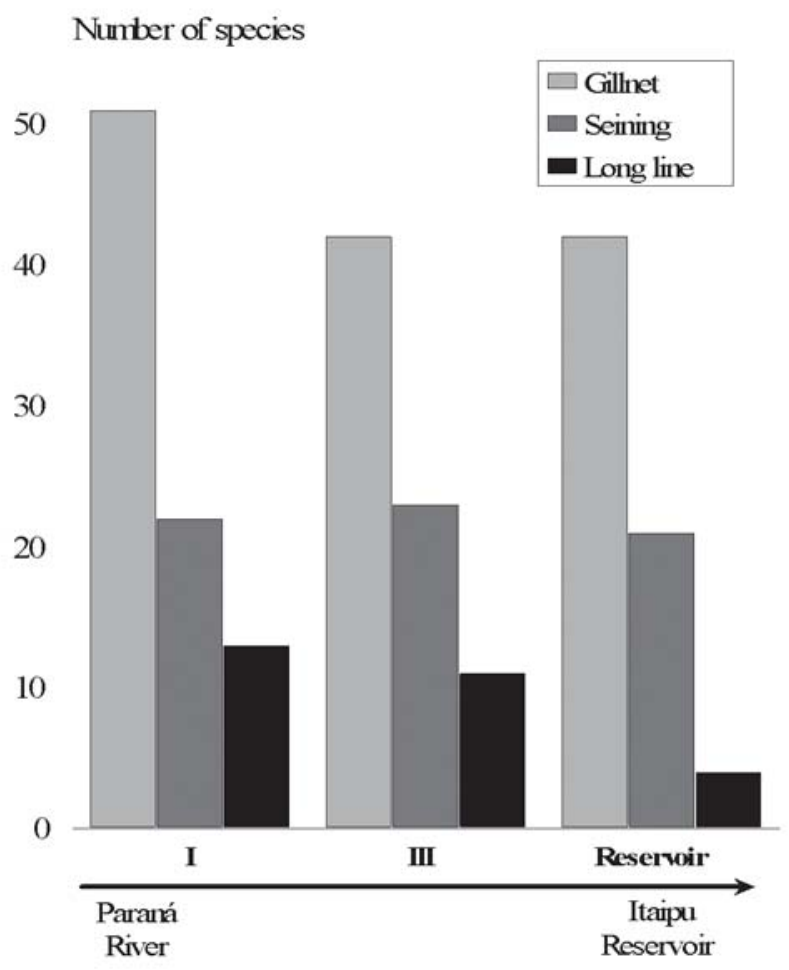

Fig. 5. Number of species sampled with the same fishing gear in the segments I, III, and Reservoir. 
Considering that the fish pass system must preferentially provide the upward movement of migratory species, the distribution of migrators sampled with the different types of gear is presented from downstream to upstream direction in Table 2. Note that the highest number of migratory species (16) was recorded in Segment I, and decreased in the upper segments. Apparently, the species that ascend the Canal da Piracema with no great difficulty were L. elongatus, L. obtusidens, $P$. lineatus, and $S$. brasiliensis, all considered excellent swimmers. This suggests that this fish pass system may be having a selective effect on several migratory species. The records of some species in the higher segments may be a result of downward movement.

\section{Discussion}

The Canal da Piracema was difficult to sample because its great environmental heterogeneity, including resting pools, ladders, and nature-like fish pass. This characteristic required the use of different fishing gear, appropriate for the different biotopes, which made it difficult to define a sampling protocol. Thus, studies in the Canal da Piracema will have to be conducted, without exception, with an array of different fishing gears, which will make it difficult to compare the ichthyofauna present along its length. This was a considerable problem in this study, which led us to present the results according to the biotope sampled.

In general, the ichthyofauna present in the Canal da Piracema followed the pattern for South America and the Paraná River, with a strong predominance of Characiformes and Siluriformes, where Characidae, Anostomidae, Pimelodidae, and Loricariidae were the most important families (LoweMcConnel, 1987; Agostinho \& Júlio Jr., 1999). Beloniformes was recorded only in Segment I of the Canal da Piracema, indicating the presence of species that belong to the other ichthyofaunistic province (Ringuelet et al., 1967; Bonetto, 1986). Typical species of this region are: Abramites hypesolonotus, Cynopotamus kincaidi, Hemiodus orthonops ( already recorded in Segment II), Lycengraulis grossidens, Pachyurus bonariensis, Potamorhina squamoralevis, Pseudoplatystoma fasciatum and Schizodon platae.

The majority of the abundant species are small-sized, with a strong predominance of Tetragonopterinae, as observed in other environments of the basin (Canzi et al., 1998; Agostinho \& Júlio Jr., 1999; Agostinho et al., 2004; Fernandez et al., 2007). The species most caught was Bryconamericus exodon. The proportions of species and individuals according to reproductive strategy were also similar to those of other regions of the Upper Paraná River (Agostinho et al., 2004; Suzuki et al., 2004; Gaspar da Luz et al., 2004). The great majority of the long-distance migratory species (Agostinho et al., 2003; Suzuki et al., 2004) were also caught, at least in Segment I.

The Bela Vista River, which shows the characteristics of a natural canal, with gentle slopes, may have contributed to the high diversity, which was possibly a result of the variety of existing habitats. In addition, the occurrence of several species below Itaipu Dam, which apparently are not succeeding in ascending, certainly contributed to the higher species richness in Segment I. Thus, the variety of biotopes along the Canal da Piracema appears to create conditions for the reproduction and development of many fish species of the Paraná River, which can live in this fish pass, and to promote the movement of the migratory species.

The requirements for movements between different aquatic environments vary among the species, including the freshwater migratory ones. In cases where dams and other structures that can obstruct a river stretch have been constructed, these obstructions have been responsible for the decline of migratory species abundance (Agostinho et al., 2005), including the disappearance of entire stocks (salmon in the Rhine, Seine, and Garonne rivers, among others, in France) (Porcher \& Travade, 2002). It is necessary to maintain free passage through all of the obstructions existing in a hydrographic basin. However, the existence of different environments required for the main stages of the life cycle (i.e., reproduction, growth and feeding) of migratory species in the upper stretches must also be considered (Agostinho et al., 2003).

Fish pass systems are constructed to reestablish connectivity among critical habitats for migratory species. Naturelike fish passes are a recent type of fish pass and are characterized by a relatively simple ("soft") engineering, which attempts to simulate a flow regime similar to that of natural creeks and streams (Jungwirth, 1996; Parasiewicz et al., 1998). These fish passes have many advantages over traditional fish pass systems, because their generally heterogeneous structure offers several velocities and depths for a great variety of species and fish sizes. In addition, they provide habitats for them to live in (Lucas \& Baras, 2001; Aarestrup et al., 2003), as is the case of the Canal da Piracema (specifically the Bela Vista River).

Two aspects have been considered crucial to determine the success of the passage of fish through a fish pass system in particular, which can be extended to canals: first, whether a fish can find the entrance to the system; and second, whether the fish will pass through the entire system. Thus, the attraction efficiency (not evaluated in the present study) must be quantified, and then the passage efficiency, which together will define the efficacy of a fish pass system as a whole (Aarestrup et al., 2003). The abrupt reduction in the fish species abundance from downstream to upstream, even for migratory species, indicates that the Canal da Piracema is acting selectively. Apparently, the greatest obstacles are the stretches of the Bela Vista River and the following fish ladder (CABV), which links the resting pool (LAIN) to the Bela Vista River, because of its hydrodynamic characteristics, such as water velocity, shallow rock-free areas, and high turbulence. Selectivity can also occur in other fish pass systems, as is the case for the fish ladder installed at the dam of Salto Morais Reservoir, on the Tijuco River (Godinho et al., 1991).

Thus, to quantify the efficacy of a fish pass system, the 
water velocity and the flow model must be compatible with the swimming capacity of the species of interest, allowing passage of all fish, and not only the best swimmers (Larinier, 2002b). The diverse hydrological characteristics along the Canal da Piracema, such as steep slopes, high water velocities, and waterfalls, among others, may prevent the passage of fish. These aspects must be evaluated to provide information that allows the engineering sector to adjust the hydraulic aspects to facilitate fish displacements. However, it will be elemental to assess the genetic addition, spawning and recruitment upstream from Itaipu Dam, including the reservoir, floodplain and tributaries of Paraná River, taking into consideration that this fish pass system was built in the context of fishery stock conservation and maintenance of migratory fish populations.

Nevertheless, a considerable problem is the possibility of mixing two distinct ichthyofaunistic provinces, previously separated by a natural barrier, the Sete Quedas waterfalls, and by Itaipu Dam after its construction. It is known that at least one of these downstream species (H. orthonops) already moved upstream, and others were already recorded downstream (Cichla spp. introduced in the basin; Leporinus octofasciatus, endemic to the upper Paraná River). Thus, the continued monitoring of the Canal da Piracema is required to evaluate possible introductions (upstream and downstream) and the impacts for the ichthyofauna caused by the connection represented by this fish pass system.

\section{Acknowledgments}

We thank Itaipu Binacional for financial and logistic support to carry out this work. CSP was supported by grants from the CNPq (Conselho Nacional de Desenvolvimento Científico e Tecnológico) (Proc. 311975/2006-2).

\section{Literature Cited}

Aarestrup, K., M. C. Lucas \& J. A. Hansen. 2003. Efficiency of a nature-like bypass channel for sea trout (Salmo trutta) ascending a small Danish stream studied by PIT telemetry. Ecology of Freshwater Fish, 12: 160-168.

Agostinho, A. A. \& H. F. Júlio Jr. 1999. Peixes da bacia do alto rio Paraná. Pp. 374-400. In: Lowe-McConnell, R.H. (Ed.). Estudos ecológicos de peixes tropicais (translation), Edusp: São Paulo.

Agostinho, A. A., A. E. A. M. Vazzoler, L. C. Gomes \& E. K. Okada. 1993. Estratificación espacial y comportamiento de Prochilodus lineatus em distintas fases del ciclo de vida, em la vida, em la planície de inundación Del alto rio Paraná y embalse de Itaipu, Paraná, Brasil. Revue D’Hydrobiologie Tropicale, 26(1): 79-90.

Agostinho, A. A., L. C. Gomes, D. R. Fernandez \& H. I. Suzuki. 2002. Efficiency of fish ladders for neotropical ichthyofauna. River Research and Application, 18(3): 299-306.

Agostinho, A. A., L. C. Gomes, H. I. Suzuki \& H. F. Júlio Jr. 2003. Migratory fishes of the Upper Paraná River Basin Brazil. Pp. 19-89. In: Carolsfeld, J., B. Harvey, C. Ross \& A. Baer (Eds.). Migratory fishes of South America: Biology, Fisheries and Conservation Status. Vitoria: World Bank, 372p.
Agostinho, A. A., L. C. Gomes, L. C. Veríssimo \& E. K. Okada. 2004. Flood regime, dam regulation and fish in the Upper Paraná River: effects on assemblage attributes, reproduction and recruitment. Reviews in Fish biology and Fisheries, 14(1): 1119.

Agostinho, A. A., S. M. Thomaz, L. C. Gomes. 2005. Conservation of the Biodiversity of Brazil's Inland Waters. Conservation Biology, 19(3):646-652

Agostinho, A. A, L. C. Gomes \& F. M. Pelicice. 2007. Ecologia e manejo de recursos pesqueiros em reservatórios do Brasil. EDUEM, Maringá, 512 p.

Bonetto, A. A. 1986. The Paraná river system. Pp. 541-555. In: Davies, B. R. \& K. F. Walkers (Eds.). The ecology river systems. Dr. W. Junk Publishers, Dordrecht.

Britski, H. A., Silimon, K. Z. S. \& Lopes, B. S. (1999). Peixes do Pantanal. Manual de identificação. Brasília: Embrapa. 184p.

Canzi, C., H. M. Fontes Jr. \& D. R. Fernandez. 1998. A ictiofuna de ocorrência no rio Bela Vista (Resumos do $4^{\circ}$ Congresso Brasileiro de Ecologia do Brasil). Belém. Faculdade de Ciências Agrárias do Pará. NETA, Pp. 592-593.

Carolsfeld, J. 2004. Evolução da Questão de Passagens para Peixes: Similaridades entre o Canadá e o Brasil. In: Projeto peixes, pessoas e águas. Mecanismos de Transposição de Peixes Brasileiros. World Fisheries Trust.

Clay, C. H. 1995. Design of Fishways and Other Fish Facilities, 2nd ed., Lewis Publishers, Boca Raton, Ann Arbor, London, Tokyo. 248 p.

Fernandez, D. R., A. A. Agostinho, L. M. Bini \& L. C. Gomes. 2007. Environmental factors related to entry and ascent of fish in the experimental ladder located close to the Itaipu Dam. Neotropical Ichthyology, 5(2): 153-160.

Fiorini, A. S., D. R. Fernandez \& H. M. Fontes Jr. 2006. Piracema Migration Channel. Commission Internationale Des Grands Barrages. 22ème Congrès Des Grands Barrages. Barcelone.

Gaspar da luz, K. G., E. F. Oliveira, A. C. Petry, H. F. Júlio Jr, C. S. Pavanelli \& L. C. Gomes. 2004. Fish assemblages in the upper Paraná River floodplain. In: Agostinho, A. A., L. Rodrigues, L. C. Gomes, S. M. Thomaz \& L E. Miranda (Eds.). Structure and functionning of the upper Paraná River and its floodplain. EDUEM, Maringá. 2004. 275p.

Gauch Jr., H. G. 1982. Multivariate analysis in community ecology. Cambridge: CambridgeUniversity Press. 298p.

Godinho, H. P., A. L. Godinho, P. S. Formagio \& V. C. Torquato. 1991. Fish ladder efficiency in a southearstern Brazilian river. Ciência e Cultura, 43(1): 63-67.

Gomes, L. C. \& A. A. Agostinho. 1997. Influence of the flooding regime on the nutritional state and juvenile recruitment of the curimba, Prochilodus lineatus Steindachner, in the Upper Paraná River, Brazil. Fisheries Management and Ecology, 4(4): 263274.

Jungwirth, M. 1996. Bypass channels at weirs as aprópiate aids for fish migration in rhithral rivers. Regulated Rivers: Research and Management, 2: 483-492.

Larinier, M. 2002a. Fishways: General considerations. Pp. 21-27. In: Larinier, M., F. Travade, J. P. Porcher (Eds.). Fishways: Biological basis, design criteria and monitoring. Bulletin Français de la Pêche et de la Pisciculture, 364 suppl.

Larinier, M. 2002b. Biological factors to be taken into account in the design of fishways, the concept of obstruction to upstream migration. Pp. 28-38. In: Larinier, M., F. Travade, J. P. Porcher (Eds.). Fishways: Biological basis, design criteria and monitoring. Bulletin Français de la Pêche et de la Pisciculture, 364 supl. 
Lowe-McConnell, R. H. 1987. Ecological Studies in Tropical Fish Communities. Longman Press, London, 382p.

Lucas, M. C. \& E. Baras. 2001. Migration of Freshwater Fishes. Blackwell Science Ltd. 420p.

Martins, S. L. 2000. Sistemas de transposição de peixes. Unpublished Dissertation, Escola Politécnica da Universidade de São Paulo, São Paulo. 184p.

Matthews, W. J. 1998. Patterns in freshwater fish ecology. Chapmann \& Hall, New York. 756p.

Miranda, L. 2001. Dams, fish and fisheries: Opportunities, challenges and conflict resolution (eds. G. Marmulla). FAO Fisheries Technical Paper, Rome, 91-138.

Olden, J. D., D. A. Jackson \& P. R. Peres-Neto. 2001. Spatial isolation and fish communities in drainage lakes. Oecologia, 127: 572-585.

Orsborn, J. F. 1987. Fishways - Historical Assessment and Design Practices. In: Common Strategies of Anadromous and Catadromous Fishes, Bethesda, Maryland, USA: American Fisheries Society.

Parasiewicz, P. J. Eberstaller, S. Weiss \& S. Schmutz. 1998. Conceptual guidelines for nature-like bypass channels. Pp. 348362. In: Jungwirth, M., S. Schmutz \& S. Weiss (Eds.). Fish migration and fish bypasses. Oxford: Fishing News Books, Blackwell Science Ltd. 438p.

Porcher, J. P. \& F. Travade. 2002. Fishways: biological basis, design criteria and monitoring. Bulletin Francais de la Peche et de la Pisciculture, 9-20.

Quirós, R. 1988. Estructuras para assistir a los peces no salmónidos en sus migraciones: America Latina. Instituto Nacional de Investigación Y Desarollo Pesquero. FAO, 50p.

Reis, R. E., S. O. Kullender \& C. J. Ferraris Jr. (Eds.). 2003. Check list of the freshwater fishes of South and Central America. Porto Alegre, EDIPUCRS, 729p.

Graça, W. J. \& Pavanelli, C. S. 2007. Peixes da planície de inundação do alto rio Paraná é áreas adjacentes. Maringá: Eduem. 241p.

Suzuki, H. I., A. E. A. M. Vazzoler, E. E. Marques, M. L. A. P Lizama \& P. Inada. 2004. Reproductive ecology of fish assemblages. Pp. 271-292. In: Thomaz, S. M., A. A. Agostinho \& N. S. Hahn (Eds). The Upper Paraná River Floodplain: physical aspects, ecology and conservation. Leiden: Backhuys Publishers. 393p.

Vazzoler, A. E. A. de M. 1996. Biologia da Reprodução de Peixes Teleósteos: Teoria e Prática. EDUEM, Maringá, Paraná. 169p.
Appendix 1. List of species registered in the Canal da Piracema (according to reis et al., 2003). Long distance migratory species are in bold.

Myliobatiformes

Potamotrygonidae

Potamotrygon falkneri Castex \& Maciel, 1963 - "arraia"

Potamotrygon hystrix (Müller \& Henle, 1841) - "arraia"

Potamotrygon motoro (Müller \& Henle, 1841) - "arraia"

Potamotrygon sp. - "arraia"

Clupeiformes

Engraulidae

Lycengraulis grossidens (Agassiz, 1829) - "sardinha"

Characiformes

Parodontidae

Apareiodon affinis (Steindachner, 1879) - "canivete"

Curimatidae

Cyphocharax gilli (Eigenmann \& Kennedy, 1903) - "branquinha" Potamorhina squamoralevis (Braga \& Azpelicueta, 1983) "branquinha comum"

Steindachnerina brevipinna (Eigenmann \& Eigenmann, 1889)"sagüiru"

Steindachnerina conspersa (Holmberg, 1891) - "sagüiru"

Steindachnerina insculpta (Fernandes-Yépez, 1948) - "sagüiru"

Prochilodontidae

Prochilodus lineatus (Valenciennes, 1836) - "curimba"

Anostomidae

Abramites hypselonotus (Günther, 1868) - "piau-pedra"

Leporellus vittatus (Valenciennes, 1850) - "solteira"

Leporinus elongatus Valenciennes, 1850 - "piapara" Leporinus friderici (Bloch, 1794) - "piau"

Leporinus lacustris Campos, 1945 - "piava de lagoa"

Leporinus macrocephalus Garavello \& Britski, 1988 - "piauçu”" Leporinus obtusidens (Valenciennes, 1836) - "piapara"

Leporinus octofasciatus Steindachner, 1915 - "ferreirinha"

Leporinus striatus Kner, 1858 - "canivete"

Schizodon borellii (Boulenger, 1900) - "piava"

Schizodon isognathus Kner, 1858 - "piava"

Schizodon nasutus Kner, 1858 - "taguara"

Schizodon platae (Garman, 1890) - "piava"

Schizodon sp. - "piava"

Crenuchidae

Characidium aff. zebra Eigenmann, 1909 - "canivete"

Hemiodontidae

Hemiodus orthonops Eigenmann \& Kennedy, 1903 - "bananinha"

Characidae

Aphyocharax sp. - "piqui"

Astyanax spp. - "tambiú"

Astyanax altiparanae Garutti \& Britski, 2000 - "tambiú"

Astyanax asuncionensis Géry, 1972 - "tambiú"

Astyanax fasciatus (Cuvier, 1819) - "tambiú"

Brycon hilarii (Valenciennes, 1850) - "piraputanga"

Brycon orbignyanus (valenciennes, 1850) - "piracanjuba"

Bryconamericus exodon Eigenmann, 1907 - pequira"

Cynopotamus kincaidi (Schultz, 1950) - "saicanga"

Galeocharax humeralis (Valenciennes, 1834) - "saicanga"

Galeocharax knerii (Steindachner, 1879) - "saicanga"

Hemigrammus marginatus Ellis, 1911 - "lambari"

Hyphessobrycon sp. - "lambari" 
Jupiaba acanthogaster (Eigenmann, 1911) - "lambari"

Metynnis lippincottianus (Cope, 1870) - "pacu-peva"

Metynnis mola Eigenmann \& Kennedy, 1903 - "pacu-peva"

Moenkhausia spp. - "lambari, lambari-corintiano"

Moenkhausia dichroura (Kner, 1858) - "lambari-corintiano"

Moenkhausia intermedia Eigenmann, 1908 - "lambari-corintiano"

Odontostilbe sp. - "lambari"

Myloplus tiete (Eigenmann \& Norris, 1900) - "pacu-peva"

Mylossoma duriventre (Cuvier, 1818) - "pacu-prata"

Piaractus mesopotamicus (Holmberg, 1887) - "pacu"

Roeboides microlepis (Reinhardt, 1851) - "saicanga"

Roeboides paranensis Pignalberi, 1975) - "dentudo"

Salminus brasiliensis (Cuvier, 1816) - "dourado"

Serrasalmus maculatus Kner, 1858 - "piranha"

Serrasalmus marginatus Valenciennes, 1837 - "piranha"

Tetragonopterus argenteus Cuvier, 1816 - "sauá"

Triportheus nematurus (Kner, 1858) - "sardinha"

Acestrorhynchidae

Acestrorhynchus lacustris (Lütken, 1875) - "peixe-cachorro"

Acestrorhynchus pantaneiro Menezes, 1992 - "peixe-cachorro"

Cynodontidae

Rhaphiodon vulpinus Agassiz, 1829 - "dourado-facão"

Erythrinidae

Hoplias sp. - "traíra"

Siluriformes

Loricariidae

Farlowella isbruckeri Retzer \& Page, 1997

Farlowella sp.

Hypostomus spp. - "cascudo"

Hypostomus commersoni Valenciennes, 1836 - "cascudo"

Liposarcus anisitsi (Eigenmann \& Kennedy, 1903) - "cascudo"

Loricariichthys platymetopon Isbrücker \& Nijssen, 1979 -

"cascudo-chinelo"

Loricariichthys rostratus Reis \& Pereira, 2000 - "cascudochinelo"

Loricariichthys spp. - "cascudo-chinelo"

Megalancistrus parananus (Peters, 1881) - "cascudo-abacaxi"

Otocinclus vittatus Regan, 1904 - "cascudinho"

Heptapteridae

Pimelodella gracilis (Valenciennes, 1835) - "mandi-chorão"

Pimelodella griffini Eigenmann, 1917 - "mandi-chorão"

Pimelodella taenioptera Miranda Ribeiro, 1914 - "mandi-chorão"

Pimelodella spp. - "mandi-chorão"

Rhamdia quelen (Quoy \& Gaimard, 1824) - "jundiá”

Pimelodidae

Hemisorubim platyrhynchos (Valenciennes, 1840) - "jurupoca" Hypophthalmus edentatus Spix, 1829 - "mapará"

Iheringichthys labrosus (Lütken, 1874) - "mandi"

Pimelodus absconditus Azpelicueta, 1995 - "mandi"

Pimelodus maculatus Lacépède, 1803 - "mandi"

Pimelodus mysteriosus Azpelicueta, 1998 - "mandi"

Pimelodus ornatus Kner, 1858 - "mandi"

Pinirampus pirinampu (Agassiz, 1829) - "barbado"

Pseudoplatystoma corruscans (Spix \& Agassiz, 1829) - "pintado"

Pseudoplatystoma fasciatum (Linnaeus, 1766) - "cachara"

Zungaro jahu (Ihering, 1898) - "jaú"

Doradidae

Pterodoras granulosus (Valenciennes, 1821) - "armado"

Trachydoras paraguayensis (Eigenmann \& Ward, 1907) "armadinho"
Auchenipteridae

Auchenipterus osteomystax Ribeiro, 1918 - "surumanha"

Parauchenipterus galeatus (Linnaeus, 1766) - "cangati”

Gymnotiformes

Gymnotidae

Gymnotus inaequilabiatus (Valenciennes, 1839) - "morenita"

Gymnotus paraguensis Albert \& Crampton, 2003 - "morenita"

Sternopygidae

Eigenmannia sp. - "itu'"

Eigenmannia trilineata López \& Castello, 1966 - "ituí"

Eigenmannia virescens (Valenciennes, 1836) - "ituí"

Sternopygus macrurus (Bloch \& Schneider, 1801) - "ituí"

Apteronotidae

Apteronotus albifrons (Linnaeus, 1766) - "ituí-cavalo"

Apteronotus caudimaculosus Santana, 2003 - "ituí-cavalo"

Porotergus ellisi Arámburu, 1957 - "ituí-cavalo"

Beloniformes

Belonidae

Potamorrhaphis eigenmanni Miranda Ribeiro, 1915 - "peixe-agulha"

Synbranchiformes

Synbranchidae

Synbranchus marmoratus Boch, 1785 - "mussum"

Perciformes

Sciaenidae

Pachyurus bonariensis Steindachner, 1879 - "pescada"

Plagioscion squamosissimus (Heckel, 1840) - "curvina"

Cichlidae

Cichla spp. - "tucunaré"

Cichlasoma dimerus (Heckel, 1840) - "cará"

Crenicichla britskii Kullander, 1982 - "joaninha”

Crenicichla haroldoi Luengo \& Britski, 1974 - "joaninha"

Crenicichla lepidota Heckel, 1840 - "joaninha"

Crenicichla niederleinii (Holmberg, 1891) - "joaninha”

Crenicichla spp. - "joaninha"

Crenicichla vittata Heckel, 1840 - "joaninha”

Oreochromis niloticus (Linnaeus, 1758) - "tilápia-do-nilo"

Satanoperca pappaterra (Heckel, 1840) - "cará"

Pleuronectiformes

Achiridae

Catathyridium jenynsii (Günther, 1862) - "linguado"

Received January 2007

Accepted June 2007 